\title{
Growth performances and natural diet of European eel (Anguilla anguilla L.) reared in muddy and sandy ponds
}

\author{
Oliviero Mordenti ${ }^{1, \text { a }}$, Andrea Di Biase ${ }^{1}$, Antonio CASAlini ${ }^{1}$, Pietro EMmanuele ${ }^{1}$, Paolo Melotti ${ }^{2}$ \\ and Alessandra RONCARATI ${ }^{2}$ \\ 1 Department of Veterinary Medical Sciences, University of Bologna, 47042 Cesenatico, Italy \\ 2 School of Biosciences and Veterinary Medicine, University of Camerino, 62024 Matelica, Italy
}

Received 25 September 2015; Accepted 25 March 2016

\begin{abstract}
This study evaluated the growth performance and survival rate of Anguilla anguilla glass eels reared in $4750 \mathrm{~m}^{2}$ earthen ponds and dependent on trophic resources provided by natural macrobenthic populations. Two ponds (M ponds) had mostly muddy-soil bottom whereas the other two (S ponds) had mostly sandy-soil bottom. A total of 4795 pigmented glass eels $(0.73 \pm 0.26 \mathrm{~g})$ were stocked, at a density of $1.6 \mathrm{fish} / \mathrm{m}^{2}$. After 360 days of growth, in $\mathrm{S}$ ponds eels exhibited a final mean body weight $(15.57 \pm 5.36 \mathrm{~g})$ significantly higher than those seeded in $\mathrm{M}$ ponds $(9.85 \pm 4.11 \mathrm{~g})$. Mean final length of $S$ eels $(21.55 \pm 3.33 \mathrm{~cm})$ was statistically higher than that of M eels $(17.85 \pm 2.42 \mathrm{~cm})$. In M ponds, relatively higher abundances of Crustacea appeared to promote higher survival of glass eels in the post-seeding phase. Consequently, the relatively higher densities of eels in M ponds could have resulted in slower growth compared to eels in S ponds; however, eels grown in $\mathrm{M}$ ponds exhibited a significantly higher conditioning factor at the end of the growth period. We conclude that $\mathrm{M}$ ponds host highly viable macrobenthic prey populations that better sustain the early growth phases of A. anguilla. Furthermore, this study demonstrated that artificial feed supplements are not necessary for the rearing of $A$. anguilla juveniles in earthen ponds.
\end{abstract}

Keywords: European eel (Anguilla anguilla) / glass eel / pond culture / macrobenthic communities / growth performance

\section{Introduction}

Extensive fish culturing utilizes natural trophic sources to generate energy flow and enhance animal production. Differently, intensive culturing relies exclusively on supplementary energy delivered by artificial feed (Rossi et al. 1988; Bosma and Verdegem 2011). In Italy, extensive cultures are managed in coastal lagoons, and North Adriatic lagoons constitute nearly half of the total exploited Italian brackish lagoon environments. In this area, eels (Anguilla anguilla L.) are reared extensively via the traditional Vallicoltura (Mordenti et al. 2013), carried out in the Valli, a sector of a lagoon or enclosed earthen pond (Ciccotti 1997).

In the pond environment, there are close trophic interactions between the fish and their prey (Ingram and de Silva 2007); therefore, identifying the preferred prey of juvenile fish reared in earthen ponds is important for improving fish production. Managing ponds to increase the abundance of preferred prey could enhance growth and survival of cultured fish stocks. This approach, often referred to as green-water culturing, has

a Corresponding author: oliviero.mordenti@unibo.it been adopted worldwide for the rearing of numerous species of juvenile fish in earthen ponds (Egna and Boyd 1997; Castelo Branco et al. 2006; Young-Sulem et al. 2006; Ingram and de Silva 2007; Bosma and Verdegem 2011; Biswas et al. 2012), but only a few studies have investigated alimentary shifts of juvenile eels and these have been largely limited to coarse descriptions of diet (zooplankton, macroinvertebrates, and fish) (Breteler et al. 1990). Macrobenthic populations in coastal lagoons normally exhibit high spatial variability as their distribution can be influenced by various environmental parameters including salinity, water exchange ratio, and bottom characteristics, among others (Guelorget and Perthuisot 1992; Ponti et al. 2005). Identifying the ideal habitat for macrobenthic populations that yield higher survival and growth of glass eels would in turn lead to enhanced production of juvenile eels that can be reared for silver eel production in Valli (Parisi et al. 2014). The objectives of the present study were to evaluate the productive performances (final mean weight, condition factor, specific growth rate and final density) and survival rate of the European eel, starting from the glass eel phase, reared in earthen ponds with different bottom characteristics. 
Table 1. Types of substrate in ponds and farming parameters of $A$. anguilla during growth phase.

\begin{tabular}{ccc}
\hline & \multicolumn{2}{c}{ Growth } \\
\hline Pond & $n$ & 4 \\
Sandy substrate size & $\mu \mathrm{m}$ & $125-500$ \\
-incidence & $\%$ & $70 \pm 5$ \\
Muddy substrate size & $\mu \mathrm{m}$ & $4-63$ \\
-incidence & $\%$ & $65 \pm 7$ \\
Area & $\mathrm{m}^{2}$ & 750 \\
Volume & $\mathrm{m}^{3}$ & 900 \\
Stocking density & $n \mathrm{total}^{2}$ & 1200 \\
density & $n / \mathrm{m}^{2}$ & 1.6 \\
Days & $n$ & 360 \\
Initial mean weight & $\mathrm{g}$ & $0.73 \pm 0.26$ \\
Initial mean length & $\mathrm{mm}$ & $8.89 \pm 0.95$ \\
Food type & & Natural \\
Water origin & & Lagoon water \\
Flow rate & & Closed \\
Type of water circulating system & & - \\
\hline
\end{tabular}

\section{Materials and methods}

In May 2013, glass eels were captured from two different river mouths, (Tevere River: $41^{\circ} 44^{\prime} 25.97^{\prime} \mathrm{N}-12^{\circ} 14^{\prime} 00.2^{\prime \prime} \mathrm{E}$; Marta River: $\left.42^{\circ} 14^{\prime} 06.75^{\prime \prime} \mathrm{N}-11^{\circ} 41^{\prime} 44.12^{\prime \prime} \mathrm{E}\right)$, in central Italy. They were transferred to an experimental station of the Bonello Valle, a small coastal lagoon (50 ha) located in northeastern Italy. For the trial, $3.5 \mathrm{~kg}$ of pigmented glass eels $(n=$ 4,795 fish; $0.73 \pm 0.26 \mathrm{~g}$ body weight) $(\mathrm{BW})$ were distributed at random into $4750 \mathrm{~m}^{2}$ ponds. The ponds differed in sediment type in relation to the prevalence of sandy $(\mathrm{S})$ or muddy $(\mathrm{M})$ substrate (S:M ratio) (Table 1): two ponds (S ponds) were characterized by a mostly sandy-soil bottom (3:1); the other two (M ponds) had a mostly muddy-soil bottom (1:3). The water depth in each pond was $1.2 \mathrm{~m}$ (Table 1) and glass eels were stocked at the initial density of $1.6 \mathrm{fish} / \mathrm{m}^{2}$.

One month before the beginning of the growth phase, all the ponds were drained and allowed to dry for 7 days. The bottoms were levelled and then filled with brackish water coming from the Bonello Valle. The water was filtered with a $5 \mathrm{~mm}$ mesh net to prevent the introduction of large organisms into the ponds, especially predatory fish. There was no flow to or from the ponds, nor was supplementary aeration provided during the growth experiment. To prevent bird predation, the ponds were protected with a $12 \mathrm{~cm}$ side mesh net. The growing phase lasted 360 days, from July 2013 (T0, Start of the experiment) to June 2014 (T4, Day 360). Samples were carried out at different times: September 2013 (T1, Day 95), November 2013 (T2, Day 155), March 2014 (T3, Day 272). Water temperature $\left({ }^{\circ} \mathrm{C}\right)$ and dissolved oxygen $(\mathrm{mg} \mathrm{L})$ were measured daily $(9-$ 11 a.m.) in all ponds using portable electronic devices (Mod Hanna Instr. mod HI9146), and water salinity was monitored weekly using a salinometer (Milwaukee mod MR100ATC).

At the same times, in order to evaluate the composition and abundance of macrobenthic communities, six substrate samples (surface: $115 \mathrm{~cm}^{-2}$; thickness: $12 \mathrm{~cm}$ ) were collected from the bottom of each $\mathrm{S}$ and $\mathrm{M}$ ponds, at the same distance among them, using a coring device. Macrobenthic organisms were separated by repeatedly suspending each sediment sam- ple in water and decanting the supernatant into a $250 \mu \mathrm{m}$ test sieve. The macrobenthic community was described following Borja et al. (2000) and Ponti et al. (2005) by computing the mean abundance of each taxon at each sample site. The species richness was determined as relative distribution (rate of macrobenthic species) and density $\left(\mathrm{n} .100 \mathrm{~cm}^{-2}\right)$. Taxon identification was performed in the laboratory by means of a binocular microscope (4-40X).

Fish sampling in $\mathrm{M}$ and $\mathrm{S}$ ponds was performed using traps and fishing nets (30 eels per pond) and coincided with the sampling of the macrobenthic community. All the fish samplings were carried out at the same time of the day (6:00 a.m.). A winter sampling was not performed in order to prevent captureinduced mortality and, because fish are more active during late spring and summer, the environmental effects on growth are more evident (Carvalho et al. 2007). The fish captured from each pond were individually weighed to the nearest $0.01 \mathrm{~g}$ with electronic balance scales (Bel Engineering mod. Mark K12); total body length (BL; measured from the most anterior extremity to the caudal fin, squeezed to give the maximum length measurement) was determined to the nearest millimeter using an ictiometer. Condition factor $(K)$ was calculated according to the formula $K=\left(B W \times B L^{-3}\right) \times 10^{3}$ where $B W$ : body weight (g), $B L$ : body length $(\mathrm{cm})$ (Mordenti et al. 2013). At T2 and T4, 20 eels per pond were randomly selected and immediately sacrificed with an overdose of anaesthetic (2-phenoxyethanol) in order to excise their stomach and determine the gut fullness index (GFI) according to the procedure indicated by Ingram and de Silva (2007). GFI values were determined as one of three categories: GFI 0 (zero) = empty stomach; GFI 1/2 = half full stomach; GFI 1 = full stomach.

At the end of the growth phase, the all ponds were drained and all fish were harvested. All eels were counted and 100 specimens per pond were individually weighed and measured in order to evaluate growth performances $(B W, B L$ and $K)$ of fish reared in ponds with different bottom types. Survival rate was recorded as percentage of fish harvested in relation to the number of fish stocked at the beginning of growth phase. The specific growth rate (SGR), was expressed as the percentage increase in $B W$ per day $\left(\%\right.$ day $\left.^{-1}\right)$ using the following formula:

$$
S G R=100 \times\left(\ln B W_{t}-\ln B W_{0}\right) / t ;
$$

where $t$ is time in days; $\ln W_{0}$ is the natural logarithm of the average body weight at time zero; $\ln W_{t}$ is the natural logarithm of the average body weight at time $t$ (Ingram et al. 2001).

Zootechnical performances of eels reared in $\mathrm{M}$ and $\mathrm{S}$ ponds were compared using a one-way analysis of variance (ANOVA; SSP software, Smith's Statistical Package). The means were separated by a Student Newmann Keuls test. Differences were considered statistically significant at $p \leqslant 0.01$.

All the fish were handled in accordance with the European Union regulations concerning the protection of experimental animals (Dir 86/609/EEC). Approval for this study was obtained by Ethics Committee of Bologna University.

\section{Results}

Several growth parameters varied significantly between eels reared in $\mathrm{M}$ and $\mathrm{S}$ ponds at T4. Eels in S ponds exhibited a 
Table 2. Growth performances of eels in the two different ponds.

\begin{tabular}{cccc}
\hline & & S ponds & M ponds \\
\hline Initial mean weight & $\mathrm{g}$ & $0.73 \pm 0.26$ & $0.73 \pm 0.26$ \\
Initial mean length & $\mathrm{mm}$ & $8.89 \pm 0.95$ & $8.89 \pm 0.95$ \\
Initial condition factor $(K)$ & & $1.04 \pm 0.31$ & $1.04 \pm 0.31$ \\
Final mean weight & $\mathrm{g}$ & $15.57 \pm 5.36^{\mathrm{a}}$ & $9.85 \pm 4.11^{\mathrm{b}}$ \\
Final mean length & $\mathrm{mm}$ & $21.55 \pm 3.33^{\mathrm{a}}$ & $17.85 \pm 2.42^{\mathrm{b}}$ \\
Final condition factor $(K)$ & & $1.43 \pm 0.14^{\mathrm{b}}$ & $1.63 \pm 0.14^{\mathrm{a}}$ \\
SGR & $\% / \mathrm{d}$ & $0.850^{\mathrm{a}}$ & $0.723^{\mathrm{b}}$ \\
Final specimen density & $\mathrm{kg} /$ pond & $12.74 \pm 0.8$ & $9.96 \pm 0.60$ \\
Survival rate & $n /$ pond & $818.4 \pm 51.6$ & $1011.6 \pm 61.2$ \\
& $\%$ & $68.2 \pm 4.3^{\mathrm{b}}$ & $84.3 \pm 5.1^{\mathrm{a}}$ \\
\hline
\end{tabular}

Different letters $(\mathrm{a}, \mathrm{b})$ on the same line indicate significant differences, with $\mathrm{a}>\mathrm{b}(p<0.01)$.

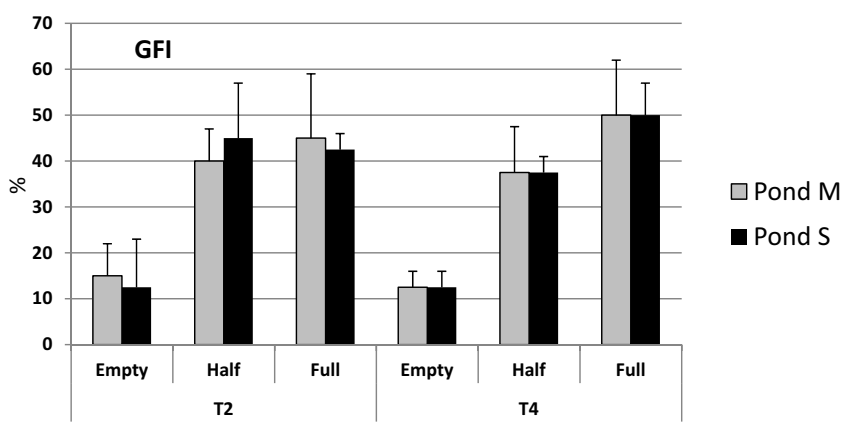

Fig. 1. Gut Fullness Index (GFI) registered at the end of growth phases $\mathrm{T} 2$ and $\mathrm{T} 4$.

final mean body weight $(15.57 \pm 5.36 \mathrm{~g})$ that was significantly higher than those eels seeded in M ponds $(9.85 \pm 4.11 \mathrm{~g})$; the mean final length of $\mathrm{S}$ eels $(21.55 \pm 3.33 \mathrm{~cm})$ was also statistically higher than those of M eels $(17.85 \pm 2.42 \mathrm{~cm}$; Table 2$)$. SGR was also significantly higher for eels reared in $\mathrm{S}$ ponds (Table 2). Condition factor $(K)$ steadily increased during the growth period in both pond types; however, in contrast to the differences in body weight and length at T4, the $K$ value of eels reared in $\mathrm{M}$ ponds $(1.63 \pm 0.14)$ was significantly higher those reared in $\mathrm{S}$ ponds (1.43 \pm 0.14 ; Table 2$)$. Eel survival rate at the end of the trial was also significantly higher in $\mathrm{M}$ ponds (Table 2). The GFI of eels reared in $\mathrm{M}$ and $\mathrm{S}$ ponds was not significantly different (Fig. 1). Empty stomach percentage was very low at both $\mathrm{T} 2$ and T4, and was never higher than $15 \%$.

Macrobenthos analysis identified 12 taxa, 7 of which were classified at the species level. The most abundant species were Cerastoderma glaucum and Abra alba for Bivalves, Hydrobia ventrosa for Gastropoda, Corophium spp. for Crustaceans, and Polichaeta were represented exclusively by Neanthes succinea. At the beginning of the growth phase (T0), M and S ponds exhibited a macrobenthic faunal community that contained the same four taxa (Fig. 2). However, the relative distribution of species in the two pond types was significantly different; in M ponds it was mainly composed of Crustaceans (58.2\%, 93\% of which were Corophium spp.), followed by Polichaeta, Bivalves, and Gastropoda. S ponds were mainly inhabited by Polichaeta $(60.5 \%$, all of which were Neanthes succinea), followed by Bivalves, Crustaceans and Gastropoda (Fig. 2). The total macrobenthic population showed a more significant density in $\mathrm{M}$ ponds than that observed in $\mathrm{S}$ ponds (12.7 animals. $100 \mathrm{~cm}^{-2}$ vs. 4.3 animals. $100 \mathrm{~cm}^{-2}$ respectively; Fig. 2). As concerns the different taxa, only Crustacea exhibited significant difference in favour of $\mathrm{M}$ ponds compared to $\mathrm{S}$ ponds ( 7.4 animals. $100 \mathrm{~cm}^{-2}$ vs. 0.5 animals. $100 \mathrm{~cm}^{-2}$ respectively; Fig. 2).

Similar trends were observed for the macrobenthic community composition in both pond types during the eel growth period (Fig. 3). In all the ponds of both the types, the relative abundances of Polichaeta and Crustaceans significantly decreased over time, and consequently, Bivalves and Gastropoda notably increased during the growth period. The largest reduction of Crustacea $(67.2 \%$ in $\mathrm{S}$ ponds and $45.7 \%$ in $\mathrm{M}$ ponds) was observed during the first growth time (from T0 to T2), and a dramatic reduction in the Polichaeta population (94.1\% and $87.8 \%$ in $\mathrm{S}$ and $\mathrm{M}$ ponds, respectively) occurred during the second growth time (from T2 to T4; Fig. 3). Over the entire growth period, the macrobenthic population density was reduced by $73.4 \%$ in $\mathrm{M}$ ponds (from 12.7 to 3.3 animals. $100 \mathrm{~cm}^{-2}$ ) and $85.1 \%$ in $\mathrm{S}$ ponds (from 4.3 to 0.6 animals. $100 \mathrm{~cm}^{-2}$ ).

Water analyses and sediment samples showed high uniformity in chemical composition between the two pond types, with oxygen concentrations ranging from $5.16 \mathrm{mg} \mathrm{L}$ to $8.74 \mathrm{mg} / \mathrm{l}$ and salinity ranging from $35-40$ in summer and 20-25 in winter (Fig. 4). The maximum and minimum temperatures were $30{ }^{\circ} \mathrm{C}$ and $3.5^{\circ} \mathrm{C}$, respectively (Fig. 4).

\section{Discussion}

The present study investigated the effects of benthic communities in earthen valley ponds on feeding behavior, growth, survival, and rearing of the European glass eel. The macrobenthic invertebrate compositions observed in the two pond treatments were significantly different but qualitatively corresponded to that of a littoral ecosystem (i.e., a transitional ecosystem). The introduction of glass eels into soft-bottom earthen ponds has also been shown to impact the structure of the macrobenthic community (Carvalho et al. 2007). At seeding, all ponds exhibited high taxonomic diversity, including high abundances of Polichaeta in S ponds and Crustacea in $\mathrm{M}$ ponds. $\mathrm{M}$ ponds were richer in terms of macrobenthic density (12.7 animals. $100 \mathrm{~cm}^{-2}$ ), compared to $\mathrm{S}$ 
a. Macrobenthic distribution in S Ponds (Start)

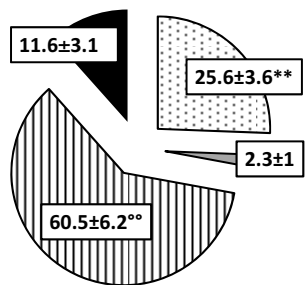

Bivalves

$\square$ Gastropoda

미 Polychaeta

- Crustaceans b. Macrobenthic distribution in M Ponds (Start)

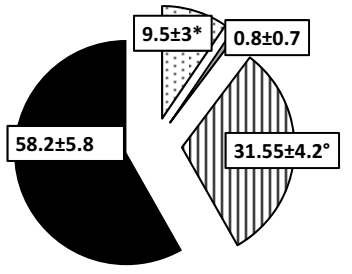

문ivalves

$\square$ Gastropoda

mPolychaeta

- Crustaceans

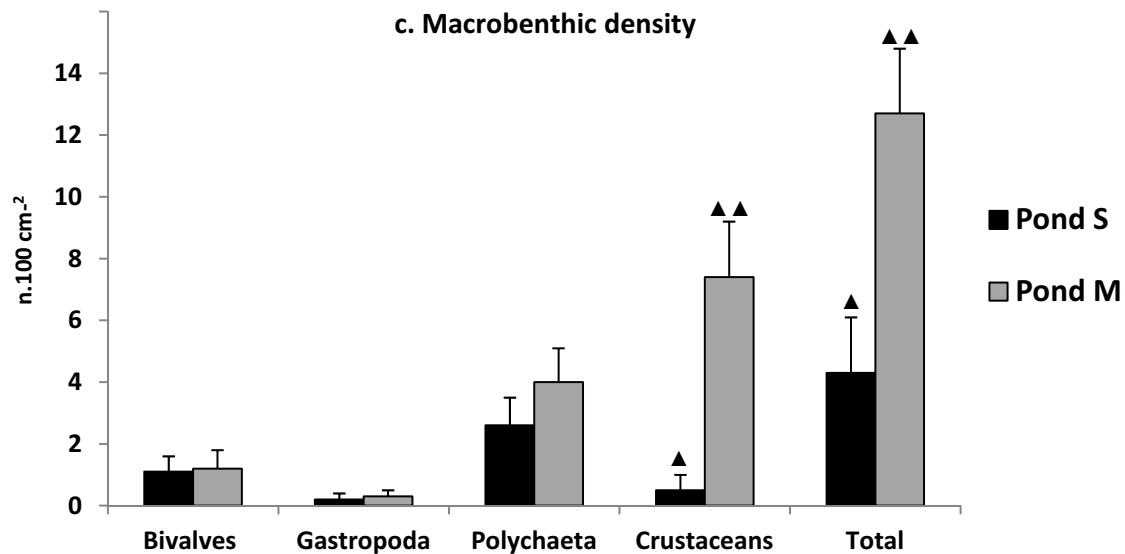

Fig. 2. Relative distribution (\%) of macrobenthic species (a, b) and macrobenthic density (c) in $\mathrm{S}$ and $\mathrm{M}$ ponds at the beginning of the growth phase. Different symbols of the same taxa show significant differences $(p<0.01)$.

ponds (4.3 animals. $100 \mathrm{~cm}^{-2}$ ). During the growth phase, organisms belonging to Crustacea and Polichaeta were reduced to $13.2 \%$ and $4.0 \%$ of the total macrobenthic population in $\mathrm{M}$ and $\mathrm{S}$ ponds, respectively. As reported by Ingram and de Silva (2007), the demand for food resources increases fish biomass.

Glass eel feeding habits shifted from an initial preference for Crustacea, which were largely reduced in both $\mathrm{M}$ and $\mathrm{S}$ ponds from T0 to T2, to Polichaeta, which almost completely disappeared from T2 to T4. This size selective feeding behavior is expected by predacious fish, as juveniles typically consume the most abundant prey within the limitations imposed by mouth gape (Fox 1989; Hapher et al. 1989; Schael et al. 1991; Christofferson et al. 1993; Ingram and De Silva 2007). Finally, the relative increases in Bivalves and Gastropoda abundance throughout the growth period could be due to their reproductive activity and relatively reduced predatory pressure, as eels seem to have avoided these species. Gut content analysis revealed that eels also rarely consumed zooplankton (i.e. rotifers and copepod nauplii), which are common and abundant in these lagoon habitats. Although it was not possible to verify if prey size increased with eel growth during the current study, juveniles fishes are expected to feed on small plankton only when prey choice is limited (Rowland 1992; Ingram and de Silva 2007).

In $\mathrm{M}$ ponds, eels showed lower weight, length and SGR but higher survival rate in comparison with juveniles in $S$ ponds. In $\mathrm{M}$ ponds, eels had an initial feeding availability more favourable probably due to the high content of Crustacea; this taxa represented almost the $60 \%$ of the benthic community and could have enhanced the survival rate in this environment. This result is in agreement with the findings of Ravagnan (1978) which showed that eels consumed Corophium spp. as the most available benthic prey in lagoon ponds. The higher stocking density partially affected the growth rate although the condition factor was favourable in all the types of pond.

\section{Conclusion}

In the $\mathrm{M}$ ponds, the high Crustacea content appeared to promote a higher survival of glass eels during the initial growth phase. Subsequently, the higher eel population density in M ponds could have negatively impacted eel growth (i.e., increases in biomass and body length), which could explain the lower condition factor $(K)$ observed upon harvest (T4) in comparison to $\mathrm{S}$ ponds. It seems that muddy ponds were more suitable for rearing eels, as they provide habitat for a macrobenthic population that is highly viable for glass eels during the initial growth phases. This is supported by the fact that eel sampling in $\mathrm{S}$ ponds was always more time consuming and labor intensive compared to $\mathrm{M}$ ponds, likely due to reduced eel abundance.

The current study demonstrated that juvenile A. anguilla can be reared in earthen ponds without supplementary artificial feeding. These results were satisfactory, although the initial stocking density used in this study was relatively low (i.e., glass eel $1.6 \mathrm{~m}^{-2}$ ) compared to those used in tank cultures (Heinsbroek and Kreuger 1992; Roncarati et al. 1997) 


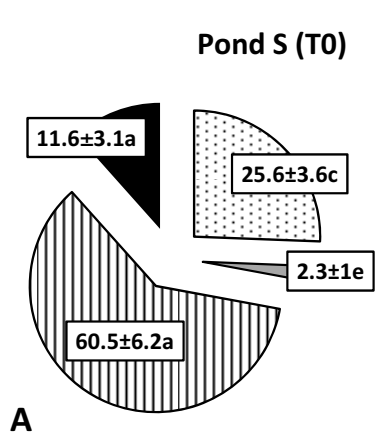

Day 1

Pond M (T0)

Day 1

A

Pond S (T1)

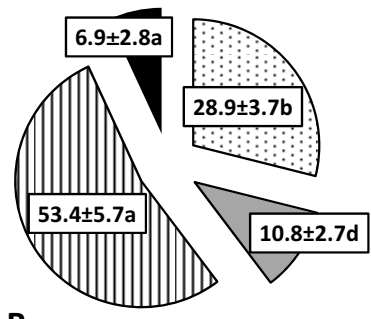

B

Pond S (T2)

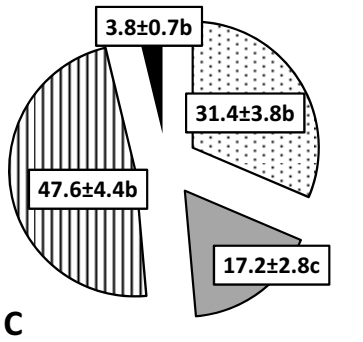

Pond S (T3)

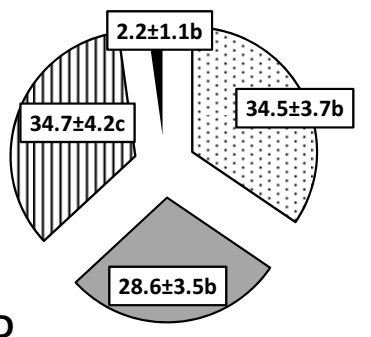

Pond S (T4)

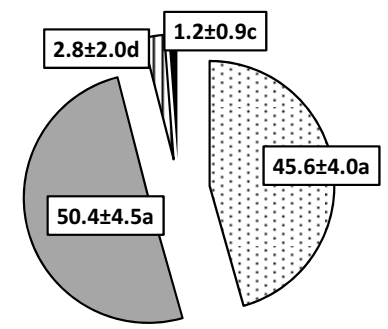

$\mathbf{E}$ $\square$ Bivalves

$\square$ Gastropoda

QPolychaeta

- Crustaceans

Day 95

๑Bivalves

口Gastropoda

口Polychaeta

- Crustaceans

Day 155

๑Bivalves

口Gastropoda

QPolychaeta

- Crustaceans

Day 272

$\square$ Bivalves

$\square$ Gastropoda

口Polychaeta

- Crustaceans

Day 360

๑Bivalves

$\square$ Gastropoda

$\square$ Polychaeta

- Crustaceans

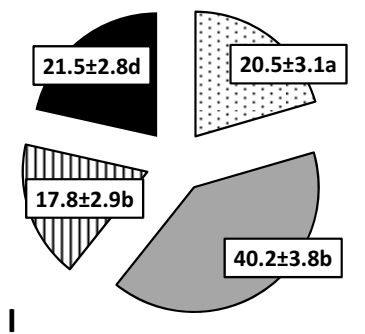

Pond M (T4)

Day 360

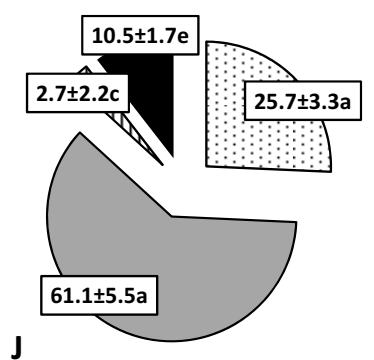

๑Bivalves

口Gastropoda

口Polychaeta

- Crustaceans

F

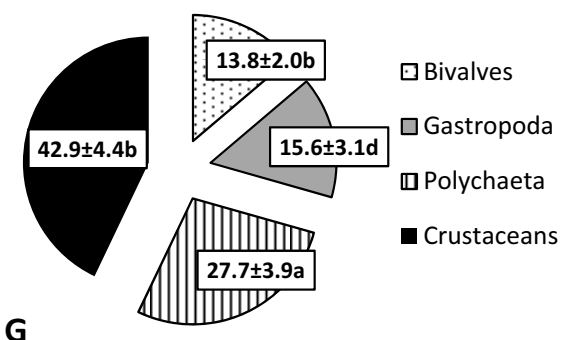

Pond M (T2)

Day 155

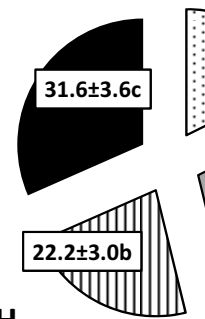

H

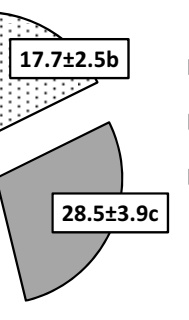

Bivalves

口Gastropoda

口Polychaeta

- Crustaceans

Day 272

๑Bivalves

口Gastropoda

口Polychaeta

- Crustaceans

$\square$ Bivalves

$\square$ Gastropoda

口Polychaeta

- Crustaceans

J

Fig. 3. Changes in the relative abundance of the macrobenthic community over the sampling period. Different letters of the same taxa, belonging to the same type of Pond, show significant differences $(p<0.01)$. 


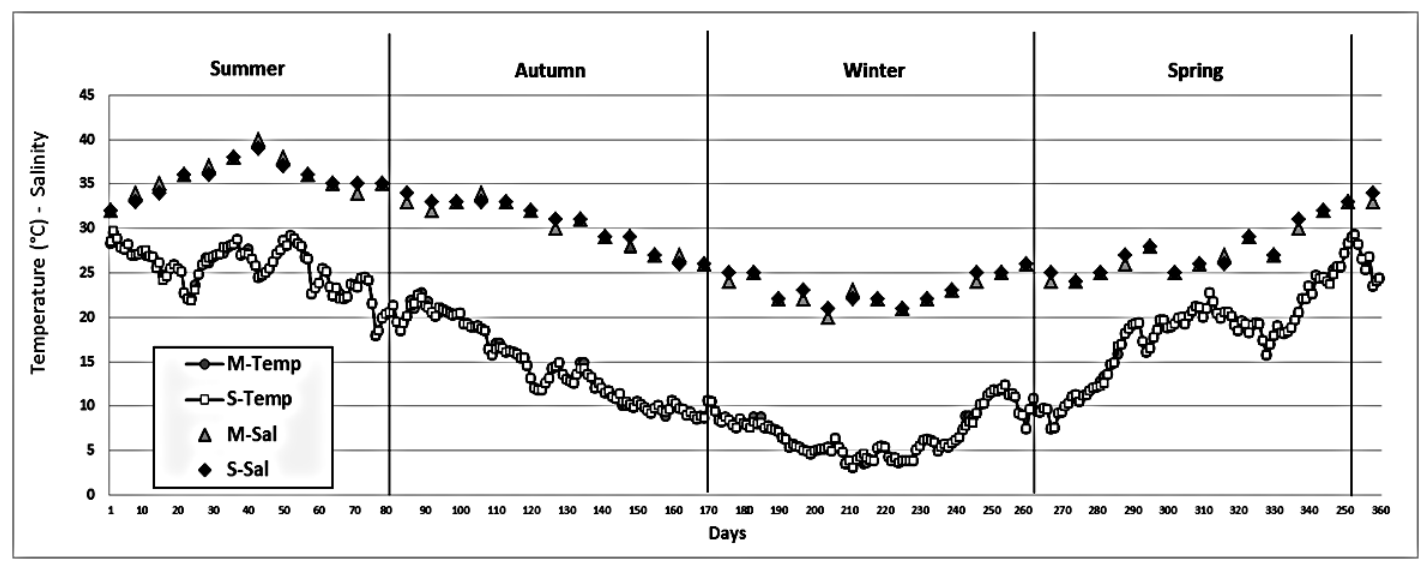

Fig. 4. Water temperature and salinity in $\mathrm{M}$ ponds and $\mathrm{S}$ ponds through the growth period.

or for A. australis in a fertilized pond (Ingram et al. 2001). Belpaire et al. (1990), after 190 days of stocking glass eels at higher initial densities in fertilized earthen ponds without supplemental feeding, obtained lower BW (1-2 g) compared to those reached in the present paper. The stocking of juvenile $A$. anguilla at high densities resulted in reduced growth in earthen ponds (Breteler et al. 1990) and tank cultures (Degani and Levanon 1983; Roncarati et al. 1997). High seeding densities, which are normally employed for intensive rearing, can lead increased feeding competition and larger variability in fish body weight. A greater size range in eels induces an increase in aggression between fish, and may result in cannibalism of smaller fish (Sadler 1979). It is possible that low seeding densities in ponds can lead to higher female eel production. Even though sexual dimorphism was not yet evident in the current study due to the small size of the fish, Tesch (1991) observed that, given equal space in nature or farming, an increase in the number of individuals corresponded to a modified sex ratio in favor of male eels, which are generally believed to grow slower than females. Ravagnan (1978) and Roncarati et al. (1997) observed that the growth of eels reared in ponds at high stocking densities tended plateau at $150 \mathrm{~g}$, due to the high number of males or specimens with male gonads.

Interestingly, the biometric parameters of glass eels observed in the current study were comparable with those of a European eel culture that was reared in captivity, using a traditional intensive technique relying on artificial food (Gousset 1990). In rearing tanks, Roncarati et al. (1997) obtained $7.5 \mathrm{~g}$ juveniles after 120-150 days, while in the current study, glass eels reared in earthen ponds increased to $10-15 \mathrm{~g}$ in 170 days. It should be taken into account that eels feed mainly when water temperature is between 18 and $30{ }^{\circ} \mathrm{C}$ (Altun et al. $2005)$, reducing the optimal growth period to 170 days out of the 360 day trial length. The water temperature remained below $30{ }^{\circ} \mathrm{C}$ in summer, while temperatures were lower than $5 \mathrm{C}$ for 22 days during winter. According to Sadler (1979) and Walsh et al. (1983), eels enter a state of numbness at temperatures varying from 1 to $5^{\circ} \mathrm{C}$, while the critical thermal maximum varies from 33 to $39{ }^{\circ} \mathrm{C}$. Increased basin depth helped to buffer temperatures and reduced eel mortality and other problems that could result from excessive cooling in winter or overheating in summer.
Acknowledgements. The authors are very grateful to Dr. Renato Palazzi, Chief Manager of the Bonello Valle, Veneto Agricoltura, Italy.

\section{References}

Altun T., Tekelioğlu N., Nevşat E., Sağat Y., 2005, Some Growth Parameters on European Eel (Anguilla anguilla L.,1758) Fed with Different Feeds. J. Fish. Aquat. Sci. 22, 215-219.

Belpaire C., von Vlasselaer L., Podoor N., Ollevier F., 1990, Short note pond culture experiments with glass eel of the European eel (Anguilla anguilla L.). Int. Rev. Hydrobiol. 75, 893-894.

Biswas G., Debasis D., Thirunavukkaruasu A.R., Natarajan M., Sundaray J.K., Kailasam M., Kumar P., Ghoshal T.K., Ponniah A.G., Sarkar A., 2012, Effects of stocking density, feeding, fertilization and combined fertilization-feeding on the performances of striped grey mullet (Mugil cephalus L.) fingerlings in brackishwater pond rearing systems. Aquaculture 338-341, 284-292.

Borja A., Franco J., Perez V., 2000, A Marine Biotic Index to Establish the Ecological Quality of Soft-Bottom Benthos Within European Estuarine and Coastal Environments. Marine Poll. Bull. 40, 1100-1114.

Bosma R.H., Verdegem M.C.J., 2011, Sustainable aquaculture in ponds: principles, practices and limits. Livestock Sci. 139, 58-68.

Breteler J.G.P.K., Dekker W., Lammens E.H.R.R., 1990, Growth and production of yellow eels and glass eels in Ponds. Int. Rev. Hydrobiol. 75, 189-205.

Carvalho S., Barata M., Gaspar M.B., Pousão-Ferreira P., da Fonseca L.C., 2007, Enrichment of aquaculture earthen ponds with Hediste diversicolor: Consequences for benthic dynamics and natural productivity). Aquaculture 262, 227-236.

Castelo Branco M.A., Moura O., Gamito S., 2006, Growth and survival of post-larval of sole (Solea senegalensis) in net cages at the bottom of earthen ponds. Aquaculture 259, 278-282.

Christofferson K., Riemann B., Klysner A., 1993, Potential role of fish predation and natural populations of zooplankton in structuring a plankton community in eutrophic lake water. Limnology and Oceanography $38,561-573$.

Ciccotti E., 1997, Italy. In: Moriarty C., Dekker W. (eds.), Management of the European Eel. Fish. Bull. 15, 91-100.

Degani G., Levanon D., 1983, The influence of low density on food adaptation, cannibalism and growth of eels (Anguilla anguilla L.). Israeli J. Aquaculture 35, 53-60. 
Egna H.S., Boyd C.E., 1997, Dynamics of pond Aquaculture. CRC Press, New York.

Fox M.G., 1989, Effect of Prey Density and Prey Size on Growth and Survival of Juvenile Walleye (Stizostedion vitreum vitreum). Canadian J. Fish. Aquat. Sci. 46, 1323-1328.

Gousset B., 1990, European eel (Anguilla Anguilla L.) farming technologies in Europe and in Japan: Application of a comparative analysis. Aquaculture 87, 209-235.

Guelorget O., Perthuisot J.P., 1992, Paralic ecosystem. Biologiacal organization and functioning. Vie et Milieu 42(2), 215-251.

Heinsbroek L.T.N., Kreuger J.G., 1992, Feeding and growth of glass eels, Anguilla anguilla L.: the effect of feeding stimulants on feed intake, energy metabolism and growth. Aquacult. Fish. Manage. 23, 327-336.

Hapher B., Milstein A., Leventer H., Teltsch B., 1989, The effect of fish density and species combination on growth and utilization of natural food in ponds. Aquacult. Fish. Manage. 20, 59-71.

Ingram B.A., De Silva S.S., 2007, Diet composition and preference of juvenile Murray cod, trout cod and Macquarie perch (Percichthyidae) reared in fertilised earthen ponds. Aquaculture 271, 260-270.

Ingram B.A., Gooley G.J., De Silva S.S., Larkin B.J., Collins R.A., 2001, Preliminary observations on the tank and pond culture of the glass eels of the Australian shortfin eel, Anguilla australis Richardson. Aquacult. Res. 32, 833-848.

Mordenti O., Di Biase A., Bastone G., Sirri R., Zaccaroni A., Parmeggiani A., 2013, Controlled reproduction in the wild European eel (Anguilla anguilla): two populations compared. Aquacult. Int. 21, 1045-1063.

Parisi G., Terova G., Gasco L., Piccolo G., Roncarati A., Moretti V.M., Centoducati G., Gatta P.P., Pais A., 2014, Current status and future perspectives of Italian finfish aquaculture. Rev. Fish Biol. Fish. 24, 15-73.
Ponti M., Della Casa C., Bacchiocchi F., Colangelo M.A., Ceccherelli V.U., 2005, Distribuzione spaziale e variazioni stagionali dei popolamenti macrobentonici nella laguna costiera "Pialassa Baiona" (Ravenna). Biologia Marina Mediterranea 12, 312-316.

Ravagnan G., 1978, Vallicoltura Moderna. Edagricole Bologna, pp. 113-118.

Roncarati A., Melotti P., Mordenti O., Gennari L., 1997, Influence of stocking density of European eel (Anguilla anguilla, L.) elvers on sex differentiation and zootechnical performances. J. Appl. Ichthyol. 13, 131-136.

Rossi R., Carrieri A., Rizzo M.G., 1988, Use of intensive rearing systems as back-up for coastal lagoon aquaculture: an experience with eels, Anguilla anguilla L., in the Comacchio lagoons. Aquacult. Fish. Manage. 19, 355-361.

Rowland S.J., 1992, Diet and feeding of Murray cod (Maccullochella peelii) larvae. Proceedings of The Linnean Society of New South Wales 113, 193-201.

Sadler K. 1979, Effects of temperature on the growth and survival of the European eel, Anguilla anguilla L. J. Fish Biol. 15, 499-507.

Schael D.M., Rudstam L.G., Post J.R., 1991, Gape Limitation and Prey Selection in Larval Yellow Perch (Perca flavescens), Freshwater Drum (Aplodinotus grunniens), and Black Crappie (Pomoxis nigromaculatus). Canadian J. Fish. Aquat. Sci. 48, 1919-1925.

Tesch F.W., 1991, Anguillidae. In: The freshwater fishes of Europe. Hoestlandt H. (Ed.), AULA-Verlag, Wiesbaden, pp. 388-437.

Walsh P.J., Foster G.D., Moon T.W., 1983, The Effects of Temperature on Metabolism of the American Eel Anguilla rostrata (LeSueur): Compensation in the Summer and Torpor in the Winter. Physiological Zoology 56, 532-540.

Young-Sulem S., Tomedi E.T., Mounchili S., Tekeng S., Brummett R.E., 2006, Survival of Clarias gariepinus fry in earthen ponds: effects of composts and leaks. Aquaculture 260, 139-144. 